providing an opportunity to spend 8 weeks during the summer working in an AATS member's cardiothoracic surgery department, the summer intern scholarship provides medical students with insight into the scientific investigation and study of cardiothoracic surgery.

A grant of $\$ 4,000$ is provided to successful applicants to underwrite their living expenses during the 8 weeks of guidance at the selected host institution. Additionally, all awardees will receive complimentary registration to the Association's 2010 Annual Meeting and postgraduate courses taking place May $1-5$ in Toronto, ON, Canada.

For more information and to submit an application, please visit the AATS Web site at www.aats.org. Application Deadline: January 15, 2010.

\section{AATS Online Award Applications Now Available at www.aats.org}

Deadline: July 1, 2010

Michael E. DeBakey Research Scholarship 2011-2013 provides an opportunity for research, training and experience for North American surgeons committed to pursuing an academic career in cardiothoracic surgery.

- Research program must be undertaken within the first three years after completion of an approved North American cardiothoracic residency.
- Applications for the scholarship must be submitted during the candidate's first two years in an academic position.

- The scholarship will begin July 1, 2011, and conclude on July 1, 2013.

- The Scholarship provides an annual stipend of $\$ 80,000$ per year paid to the host institution for direct salary support and related research expenses.

Deadline: July 1, 2010

Evarts A. Graham Memorial Traveling Fellowship, 2011-2012 grant supports training of international surgeons who have been regarded as having the potential for later international thoracic surgical leadership.

- Candidate must be a non-North American who plans a cardiothoracic surgery training program in a North American center and who has not had extensive (exceeding a total of six months in duration) clinical training in North America prior to making application.

- Candidate should have completed his/her formal training in general surgery and in thoracic and cardiovascular surgery, but should not have reached a senior position.

- The Fellowship provides a stipend of $\$ 75,000$ US, a major portion of which is intended for travel expenses incurred when visiting other medical centers.

Deadline: July 1, 2010

\section{The Western Thoracic Surgical Association}

\section{Applications for Membership}

Applications for membership in the Association must be received by the Membership Committee Chair no later than March 1, 2010 to be considered at the 2010 Annual Meeting. Applicants must be sponsored by three members of the Association who are not members of the Membership Committee. Application forms will be issued only to sponsoring members.

Address correspondence to:

Chair, Membership Committee
The Western Thoracic Surgical Association

900 Cummings Center

Suite 221-U

Beverly, MA 01915

978-927-8330; fax: 978-524-8890

wtsa@prri.com

\section{WTSA 36th Annual Meeting}

June 23-26, 2010

Ojai Valley Inn

Ojai, California

\section{The American Board of Thoracic Surgery}

\section{Notices}

The part I (written) examination was held on December 3. It is planned that this examination will be given at multiple sites throughout the United States using an electronic format. The closing date for registration is August 1 each year. Those wishing to be considered for examination must apply online at www.abts.org.

To be admissible for the Part II (oral) examination, a candidate must have successfully completed the Part I (written) examination. 